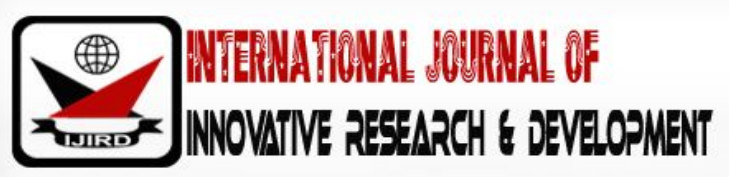

ISSN 2278 - 0211 (Online)

\section{Effects of Varying Doses of Cocos Nucifera Water on Body Weight and Blood Biochemistry of Broiler Chicks}

\author{
Ibekwe, H. A \\ Senior lecturer, Cross River University of Technology (CRUTECH), Nigeria \\ Akpet, S. 0. \\ Associate Professor, Cross River University of Technology (CRUTECH), Nigeria
}

\section{Abstract:}

Effect of 2 varying doses of Cocos nucifera water (coconut water) was investigated on body weight and blood biochemistry of broiler chicks. The body weight, dressed weight and organ weights were determined by the use of standard weighing balance. The coconut water was aseptically collected from each coconut by piercing through the eye with sharp rod. The sterile coconut water was transferred into labeled sample bottle, corked and kept for the experiment. A total of 60 two weeks old anak 2000 broiler chicks were assigned into three treatments of 20 chicks each and replicated four times of 5 chicks per replicate in a completely randomized design. Treatment one (control) received $0.00 \mathrm{mgcoconut}$ water $/ \mathrm{kg}$ body weight of birds. Treatment two and three received $200 \mathrm{mg}$ and $400 \mathrm{mg}$ of coconut water per $\mathrm{kg}$ bodyweight of birds respectively through oral intubation. The administration of experimental material was terminated after 28 days following an overnight fast. Blood was collected by venu-puncture via external jugular vein and discarded into two sample sets of bottles (one without anticoagulant and another with anticoagulant). The result obtained revealed a non-significant $(\mathrm{P}>0.05)$ non-dose dependent changes in live weight, dressed weight of broiler chicks with a significant $(\mathrm{P}<0.05)$ but non-dose dependent dressing percentage. The organ weight characteristics showed a non-significant $(\mathrm{P}>0.05)$, non-dose dependent weight changes in all the organs weighed except the gizzard that produced a significant $(\mathrm{P}<0.05)$, dose dependent reduction in weight as dosage of administration of coconut water increased. For haematological indicesthe result showed dose dependent significant $(\mathrm{P} \varangle 0.05)$ decrease in mean corpuscular haemoglobin concentration and relative white blood cell count but a significant $(\mathrm{P} \varangle 0.05)$ non-dose dependent decrease in haemoglobin concentration. Anon-significant, non-dose dependent changes were observed for red blood cells count and parked cell volume for doses of coconut water tested. For blood lipids, significant dose dependent decreases in total cholesterol and triacylglycerol were observed but a significant and non-dose dependent decrease in very low-density lipoprotein cholesterol. The serum low density lipoprotein (LDL) and high-density lipoprotein cholesterol revealed non-significant, non-dose dependent changes with the dose of coconut water administered. Alanine aminotransferase showed a significant increase but non-dose dependent activities for the two doses of administration under investigation whereas aspartate aminotransferase exhibited non-significant but dose dependent changes in activity. However, alkaline phosphatase revealed a dose dependent significant reduction in activity for the doses tested. Having no detrimental effects on body weight and organ weights with a significant $(\mathrm{P} \varangle 0.05)$ reduction in blood lipids, one will commend the use of coconut water in broiler production not above $400 \mathrm{mg} / \mathrm{kg}$ body weight of birds due to its negative response to white blood cell count, haemoglobin concentration (though not correlated at all to RBC) and alanine aminotransferase activity in this study.

Keywords: Varying doses, cocos nucifera water body weight and blood biochemistry

\section{Introduction}

Enhanced feeding strategy is the key to efficient broiler meat production. Competition with man for available conventional poultry feed sources has widened the scope of search for non-conventional feed ingredients or additive (study tiger.com, 2016). Poultry farming has been considered as one of the most progressive animal enterprises that provide meat and egg for food. Over the years, growth promoters have been added in poultry diets to promote growth, protect health and maximize the genetic potential of modern broilers and other poultry hybrids (Bozkurt et al, 2005). These growth promoters contain antibiotics that act to prevent disease, enhance growth and to obtain feed conversion efficiency. Some of the growth promoters contain arsenic which is used to control intestinal parasite, reduce stress, promote growth, improve the colour of chicken meat and produce bigger breasted chicken. Excessive use of the growth promoter may sometimes cause human disease like cancer (Basu, 2008). 
Basu (2008) further added that commercial broiler producer is at risk of developing cancer and respiratory diseases due to their inhalation of the dust from chicken feeds and waste containing these additives. These harmful side effects promoted the search and development of alternatives to achieve safe and healthier growth enhancers to broiler feeds. National feed growth promoters have been researched on and coconut water was suggested to be a good source. Coconut water and its products have gained international recognition in ancient and modern markets for its various uses.

It has been described as sport beverages in addition to its traditional use (Parades et al, 2007). It has low dry matter content (2-5) \% basis Probir et al (2014) mainly comprising sugar and mineral. Coconut water is a sweet refreshing drink taken directly from the endosperm of coconut fruit (Steiner and Desser, 2008). Coconut water is not onlya tropical beverage but has its medical value (Ediriweera, 2003). Its societal value spans from microbiological growth medium (Osazuwa and Ahonkhai, 1989), a ceremonial gift (Rethinam and Kumar, 2001), to vinegar (Sanchez et al 1985) or wine (Augustine, 2007). The different mineral composition and reasonable sugar content make coconut water a natural isotonic liquid. The properties of coconut water bequest, their uses as ideal rehydrating and refreshing drink after physical exercise (Saat et al, 2002). Its sterile nature and environment confer on it its use as a purifying medium at traditional events, in Asia especially in India (Rethinam \& Kumar, 2001). Apart from its consumption as natural drinks coconut water plays important role in traditional medicine, Indian ayurvedic medicine described coconut water as sweet, increasing semen secretion, promoting digestion and clearing the urinary tract or pathway (Rethianam and Kumar 2001). Traditionally coconut water is prescribed for burning pain during urinating, dysuria, gastritis burning pain of the eye, indigestion, hiccups or even expelling retained placenta. During world war number two and emergency in 3 rd world countries, coconut water was used as a short intravenous hydration and resuscitation fluid (Campbel- falck et al., 2000; Pummer et al, (2001). Sugars are the main fraction of soluble solid in coconut water (Lapitan and Mabesa, 1983;the main sugar in matured coconut water are sucrose, sorbitol, glucose and fructose (Del Rasario et al, 1984; Ogundiya, 1991) followed by minor sugars as galactose, xylose and Mannose. It equally contains protein, salts and small quantity of oil (Parades et al, 2007) and many authors agreed that potassium ion ( $\left.\mathrm{K}^{+}\right)$is the main mineral element (Richter et al, 2005; Uphade et al, 2008).

Although much exploration has been done on coconut water with respect to its physic-chemical properties, phytochemistry, proximate composition and mineral constituents, there are still paucity of information with respect to its in vivo effects on domestic animals in general and birds in particular. This study is therefore, designed to investigate effects of varying doses of coconut water on live weight and blood biochemistry of broiler chicks.

\section{Materials and Methods}

\subsection{Coconut Procurement}

Cocos nucifera (coconut) seeds weighing 10kg were first purchased from Apiapum market in Obubra Local Government Area of Cross River State of Nigeria. These seeds belong to the most popular variety of coconut found in the study area, the West African tall coconut cultivar. Preparation and extraction of sample was by piercing through the hard pericarp with a short but sharp metallic rod on the middle eye to gain access to the water domiciled in the endosperm. The water was aseptically collected into well labeled sample bottles for administration to experimental birds.

\subsection{Animal Procurement}

One hundred (100) day old anak 2000 broiler chicks was purchased from Abakaliki of Ebonyi State. The birds were brooded for 2 weeks before the commencement of the experiment. Feed and drinking water were supplied adlibitum. Normal and regular vaccination schedule were carried out at appropriate time with correct route and dosage of administration.

\subsection{Animal Treatment}

A total of 60 brooded birds were assigned to 3 treatments of 20 birds each with 4 replicates of 5 birds each in a completely randomized design (CRD). Treatment one (control) received $0.00 \mathrm{mg}$ of coconut water per kilogram body weight of birds. Treatment two and three received each $200 \mathrm{mg}$ and $400 \mathrm{mg}$ of coconut water per kilogram body weight of birds respectively via oral intubation. Weekly live weights of birds were taken as administration was on going. Feed and water were supplied adlibitum. The experiment was termination at the end of 4 weeks after a 24-hours starvation of birds and blood samples collected.

\subsection{Sample Collection and Analysis}

Blood samples were collected from the experimental birds via a venu-puncture of the external jugular vein with a $5.0 \mathrm{ml}$ syringe and needle. The samples were transferred into labeled sampled bottles. Half of the blood samples collected were transferred into sample bottles with anticoagulant (Ethylene diamine tetra-acetic acid EDTA) and the remaining half into bottles without anticoagulant. The samples in the later were allowed to stand for one hour and the supernatant decanted into another labeled clean sample bottles for lipid and enzyme assay. Samples in the former were used for haematology. 


\subsection{Carcass and Organ Weights Analysis}

The experimental birds were slaughtered by decapitation, de-feathered and eviscerated. The offals, heads and shanks were removed and the dressed weight taken. The organs (Lungs, heart, Liver, Kidney and Gizzard) were dismembered by deep incision and severed from the folding peritoneum and ligaments with sharp blade. The weights of various organs were taken from the different treatments and the average treatment weight compared with the control.

\subsection{Haematological Indices Analysis}

\subsubsection{Red Blood Cell Count (RBC) Nx1012/L}

This parameter was determined using autohaematology analyzer (BC-2600) of Shenzhen Mindray Biomedical Electronic Company China. A 20 -microliter of pre-capillary blood samples was diluted by $1.6 \mathrm{ml}$ of diluent. This was presented to the sample probe by pressing the aspirator key which aspirated $0.7 \mathrm{ml}$ of the sample into the analyzer. The blood cells are cells are too close to each other to be identified and counted hence the diluent is used to separate the cells so that they are drawn through the aperture one at a time as well as to create a conduciveenvironment for cell counting. The counting was monitored by inbuilt device in the autohaematology analyzer known as the metering unit. The metering unit consists of metering tubes with two optical sensors mounted on it. This tube ensures that a precise amount of diluted sample is measured during each count cycle. The exact amount is determined by the distance between the two optical sensors. The count cycle starts when the meniscus reaches the upper sensor and stops when the meniscus reached the lower sensor.

\subsubsection{Determination of Haemoglobin Concentration}

A $20 \mu \mathrm{L}$ of capillary blood sample was diluted by $1.6 \mathrm{ml}$ of diluent, thoroughly mixed and aspirated. The aspirate was delivered to both where it was bubbled mixed with certain amount of lyse which converts haemoglobin to haemoglobin complex that is measurable at 525 nanometer $(\mathrm{nm})$. The haemoglobin concentration was calculated per the following equation and expressed in $\mathrm{g} / \mathrm{dl}$ using the colorimetric method $\mathrm{Hgb}\left(\mathrm{g} / \mathrm{dl}\right.$ ) - constantx $\log _{10}$ (Blank Photocurrent/ Sample photocurrent). The other RBC-related parameters (PCV or HCT, MCHC) were calculated from the formula set out below

$\begin{array}{lll}\text { HCT (PCV) } & = & \underline{\text { RBCxMCV }} \\ \text { MCHC } & 10 & \\ & = & \underline{\text { Hgb } x 100}\end{array}$

\subsubsection{Determination of White Blood Cells (Nx10\% L)}

This was done by autohaematology analyzer after removing the $\mathrm{RBC}$ by the addition of certain amount of lyses. The stepwise procedure was as described for RBC.

\subsection{Assay of Lipid Profile}

- Estimation of total cholesterol in serum was conducted using CHOP-PAP method of Richmond, 1973. This method was based on the understanding that cholesterol esterase catalyzes the hydrolysis of cholesterol esters into free cholesterol and fatty acid. The free cholesterol is then oxidized to 4-cholesten-3-one and hydrogen peroxide in the presence of cholesterol oxidase. Phenol and 4-amino antipyrine then combine with the hydrogen peroxide in the presence of peroxidase to produce a red quinoneimine. The intensity of the colour thus produced is directly proportional to the total cholesterol concentration of the sample.

\subsubsection{Assay of High Density Lipoprotein (HDL)}

The same CHOP-PAP method of Richmond, 1973 was adopted and the procedure same as described for total cholesterol.

\subsubsection{Assay of Triacylglycerol}

This was estimated by GPO-PAP method of Trinder (1969). Triacylglycerol were determined after enzymatic hydrolysis with lipases. The indicator is quinoneimine formed from hydrogen peroxide, 4-aminophenazone and 4-chlorophenol under catalytic influence of peroxidases.

- Determination of Low density lipoprotein cholesterol (LDL) was derived from the difference between the total serum cholesterol and the sum of high density lipoprotein cholesterol (HDL)and very low-density lipoprotein cholesterol (VLDL).

- Estimation of very low-density lipoprotein cholesterol (VLDL) according to Burstein and Samaelle (1960). The VLDL concentration was obtained by dividing the serum triacyglycerol value by 5 . The relationship is based on the fact that the ratio of triacylglycerol and VLDL in human is fixed relatively at 1:5 in fasting subjects with triacylglycerol concentration not exceeding $400 \mathrm{mg} / \mathrm{dl}$. 


\subsection{Enzyme Assay}

- $\quad$ Determination of AST (Aspartate amino transferase) activity.

This was carried out according to the method of (Reitman and Frankel, 1957. AST was measured by monitoring the concentration of oxaloacetate hydrazine formed from 2, 4-dinitrophenyl hydrazine.

- $\quad$ Determination of Alanine aminotransferase (ALT).

This was carried out according to the method of Reitman and Frankel, 1957. In this case concentration of pyruvate was monitored.

- $\quad$ Estimation of alkaline phosphatase activity. This was done following the method of Belfield and Goldenberg (1971).

\subsection{Statistical Analysis}

Data collected were subjected to statistical analysis by one-way analysis of variance and significant means separated by Fisher's least significant difference (LSD).

\section{Result and Discussion}

Both live and dressed weight of broiler chicks showed a non-significant $(\mathrm{P}>0.05)$ non-dose dependent weight changes (increases or decrease) for the two doses administered as presented in table 1 relative to control. The plausible explanation to this observation stemmed from its low level of fat and very low level of carbohydrate in coconut water as reported by Conis (2011) and Probir et al (2014). Coconut water having been poor in natural sources of energy Jane (2013) does not have enough energy for conversion to flesh and hence unable to improve body weight of broilers even at higher doses. This observation was however at variance with the report of Tohala, (2010) on high positive correlation coefficient in body weight of broilers which received a low metabolizable energy diet relative to high metabolizable energy diet. The dressing percentage however, revealed a significant $(\mathrm{P}<0.05)$ but non-dosedependent changes (increase or decrease) in broiler chicks treated with $200 \mathrm{mg} / \mathrm{kg}$ body weight and $400 \mathrm{mg} / \mathrm{kg}$ body weight of birds relative to control treatment. It is worthy to note that the dressing percentage may possibly be influenced by the amount of fat removed during the dressing exercise, how lean the birds were at the slaughter time and proximity of eating to slaughter time. These factors may probably contribute to the significant $(\mathrm{P}<0.05)$ changes in dressing percentage. Assessment of percentage organ mass (weight) of broiler chicks showed a significant $(\mathrm{P}<0.05)$ dose dependent reduction in weight of gizzard of birds administered with the test doses relative to control and the rest of the organs produce non-significant, non-dose dependent organ weight changes in birds administered with the test doses relative to control. Apart from the poor energy content of coconut water (Conis, 2011) the gizzard as organ responsible for mechanical breakdown of food particlesin birds expend more energy in doing so and therefore may support the observation.

\begin{tabular}{|c|c|c|c|}
\hline Body Parameters (grams) & \multicolumn{3}{|c|}{ Varied Doses of Administration } \\
\hline & $\begin{array}{c}\text { Control T } \\
0.00 \mathrm{mg} / \mathrm{kg} \mathrm{b} . \mathrm{wt} / \mathrm{day}\end{array}$ & $\begin{array}{c}\mathrm{kg} \mathrm{b} . \mathrm{wt} \\
200 \mathrm{mg} / \mathrm{b} . \mathrm{wt} / \mathrm{day}\end{array}$ & $\begin{array}{c}\mathrm{kg} \mathrm{b} . \mathrm{wt} \\
400 \mathrm{mg} / \mathrm{b} . \mathrm{wt} / \mathrm{day}\end{array}$ \\
\hline Live weight & $1397.50 \pm 100.33$ & $1275.00 \pm 100.53$ & $700.00 \pm 100.73$ \\
\hline Dress Weight & $950.00 \pm 71.54$ & $900.00 \pm 71.44$ & $1117.50 \pm 71.64$ \\
\hline Dressing percentage (\%) & $68.21 \pm 2.22^{\mathrm{b}}$ & $90.81 \pm 2.12^{\mathrm{a}}$ & $64.17 \pm 2.34^{\mathrm{b}}$ \\
\hline Lungs & $11.00 \pm 2.84$ & $16.25 \pm 2.74$ & $12.00 \pm 2.94$ \\
\hline Liver & $38.75 \pm 3.28$ & $16.25 \pm 2.74$ & $36.25+4.28$ \\
\hline Kidney & $2.25 \pm 0.71$ & $2.50 \pm 0.81$ & $3.25 \pm 0.71$ \\
\hline Heart & $9.25 \pm 1.76$ & $10.73 \pm 1.56$ & $7.25 \pm 1.96$ \\
\hline Gizzard & $48.75 \pm 0.69 \mathrm{a}$ & $37.50 \pm 0.79 \mathrm{~b}$ & $28.00 \pm 0.89 \mathrm{c}$ \\
\hline
\end{tabular}

Table 1: Effect of Varying Doses of Cocos Nucifera Water on Body and

Organ Weight of Broiler Chicks Mean Is \pm Sem. Mean Values on the Same Row with Different Superscripts Are Significantly $(\mathrm{P}<0.05)$ Different

One way of assessing the health status of the animal used in many feeding trials experiment is the use of haematological studies (Ojebiyi et al, 2007). Presented in table 2 are the haematological parametersas affected by the test doses of Cocos nucifera water. The result presented showed a reduction in total white cell count (WBC). The word relative is used here because of undiagnosed infections observed in control treatment leading to a sharp rise in the white cell count of broiler chicks relative to the rested doses of coconut water. Nevertheless, the reduced counts $\left(17.16 \pm 3.71 \times 10^{9} / \mathrm{L}\right.$ and $\left.5.10 \pm 3.58 \times 10^{9} / \mathrm{L}\right)$ for $200 \mathrm{mg}$ and $400 \mathrm{mg} / \mathrm{kg}$ body weight are still much higher than 12-3.0x109 reference range (Orawan and Aengwanich, 2007). The non-dose dependent significant $(\mathrm{P}<0.05)$ reduction in haemoglobin concentration (not correlated with total red blood cell count) and dose dependent significant $(\mathrm{P}<0.05)$ reduction in mean corpuscular haemoglobin concentration may probably mean that there is suppressed haemopoiesis. Haematology studies have been found useful for disease prognosis, therapeutics and stress monitoring (Togun and Oseni, 2005). Energy deficient ingredient ration of energy deficient ration may influence immune system of experimental birds. Proper nutrition of birds benefits immune system and prepares the birds for the period of stress 
(Ameen et al, 2007). The red blood cell count (RBC) and parked cell volume (PCV) were however, not statistical significantly affected by the test doses of coconut water. This means that the observations made on haemoglobin and mean corpuscular haemoglobinconcentration should be interpreted with caution. The RBC is responsible for transporting oxygen throughout the body and oxygen is used as fuel to the body in tissues oxidation. High RBC numbers indicate dehydration while low count points to anemia (Jain 1993). The non-dose dependent but significant $(\mathrm{P}<0.05)$ decrease in haemoglobin concentration of birds that received the test doses of experimental material did not correlate with total $\mathrm{RBC}$ and may likely come from non-erythrocyte tissue containing haemoglobin such as Ag dopaminergic neurons, macrophages, alveolar cells and messangial cells in the kidney. Sturkie (1965) reported that haematological value in birds would be influenced by many factors, such as age, gender, hormones, hypoxia and environmental conditions. It is however, worthy of note to observe that the value of these haematological parameters are higher than the values reported by Orawan and Aengwanich (2007). Reported values Hb g/ dl-8.00-9.00; PCV\% 29-32.00; MCH\% 26.00-20.00; RBCx1012 cell/ L. 2.50-3.50 and WBCx109 cells/L. 1.20-3.00 and the corresponding observed values are Hb g/ dl 12.35-23.23; PCV\% 39.00-43.78; MCHC\% 26.49-62.64; RBCx1012 cells/ L 4.28-6.52 and WBCx109 cells/ L 5.1081.81.57 respectively.

\begin{tabular}{|c|c|c|c|}
\hline Haematological (indices) & \multicolumn{2}{|c|}{ Dosage of Administration } \\
\hline & Control $\mathrm{T}_{1} 0.00 \mathrm{mg} / \mathrm{kg} \mathrm{b} . \mathrm{wt} / \mathrm{day}$ & $\mathrm{kg} \mathrm{b} . \mathrm{wt}_{200 \mathrm{mg} / \mathrm{b} . \mathrm{wt} / \mathrm{day}} \mathrm{kg} \mathrm{b} . \mathrm{wt} 400 \mathrm{mg} / \mathrm{b} . \mathrm{wt} / \mathrm{day}$ \\
\hline $\begin{array}{c}\text { White blood cell }\left(1.0 \times 10^{9} / \mathrm{L}\right) \\
\text { (WBC) }\end{array}$ & $81.57 \pm 3.45^{\mathrm{a}}$ & $17.16 \pm 3.7^{\mathrm{b}}$ & $5.10 \pm 3.58^{\mathrm{c}}$ \\
\hline $\begin{array}{c}\text { Red blood cell }\left(1.0 \times 10^{12}\right) \\
\text { (RB) }\end{array}$ & $4.28 \pm 1.08$ & $4.78 \pm 0.98$ & $6.52 \pm 0.88$ \\
\hline Haemaglobin (g/ dl) & $23.23 \pm 1.19 \mathrm{a}$ & $12.35 \pm 2.19 \mathrm{~b}$ & $14.31 \pm 0.19 \mathrm{~b}$ \\
\hline $\begin{array}{c}\text { Mean corpuscular Haemoglobin } \\
\text { Concentration MCHC(g/ dl) }\end{array}$ & $39.02 \pm 6.78$ & $39.92 \pm 6.98$ & $43.78 \pm 7.18$ \\
\hline
\end{tabular}

Table 2: Varying Doses of Cocos Nucifera Water on Haematology of Broiler Chicks

Mean Is \pm SEM. Mean Values on the Same Row with Different Superscripts

Are Significantly $(\mathrm{P} \varangle 0.05)$ Different

Generally, the positive response of trial doses of coconut water to blood lipids of broiler chicks was observed in this study. The result as presented in table 3 revealed a dose dependent significant $(\mathrm{P}<0.05)$ reduction in serum concentration of total cholesterol as well as triacylglycerol. The report of Conis (2011) and Probir (2014) give support to this observation. The presence of phytosterol in plants may not be ruled out in this case as its presence can block cholesterol absorption during digestion causing the displaced cholesterol to be eliminated from the body (SandiBusch, 2014). The cholesterol lowering potential of coconut may be mediated by their ability to decrease levels of hydroxymethyl glutaryl - COA reductase (Quareshi, 1986). Both administrations of trial doses of coconut water did not significantly affect serum levels of low density lipoprotein cholesterol (LDL) and high-density lipoprotein cholesterol (HDL). This observation however disagreed with the report of Muller et al (2003) on significant increase in serum levels of high density lipoprotein cholesterol and low-density lipoprotein cholesterol. Very low-density lipoprotein (VLDL) cholesterol is the carrier protein for triacylglycerol and its significant reduction by the trial does of coconut water relative to control may be linked to the reduced triacylglycerol. This is because the VLDL is calculated by dividing triacylglycerol concentration by 5 .

\begin{tabular}{|c|c|c|c|}
\hline \multirow{2}{*}{ Lipid Indices (mmol/L) } & \multicolumn{2}{|c|}{ Dosage of Administration } \\
\cline { 2 - 4 } & $\begin{array}{c}\text { Control } \mathrm{T}_{1} \\
0.00 \mathrm{mg} / \mathrm{kg} \mathrm{b} . \mathrm{wt} / \mathrm{day}\end{array}$ & $\begin{array}{c}\mathrm{T}_{2} \\
200 \mathrm{mg} / \mathrm{b} . \mathrm{wt} / \mathrm{day}\end{array}$ & $\begin{array}{c}\mathrm{T}_{3} \\
400 \mathrm{mg} / \mathrm{b} . \mathrm{wt} / \mathrm{day}\end{array}$ \\
\hline Total Cholesterol & $82.05 \pm 3.12^{\mathrm{a}}$ & $59.21 \pm 3.33^{\mathrm{b}}$ & $54.65 \pm 3.34^{\mathrm{b}}$ \\
\hline Triacylglycerol & $101.74 \pm 3.69^{\mathrm{a}}$ & $81.54 \pm 3.58^{\mathrm{b}}$ & $76.25 \pm 3.70^{\mathrm{bc}}$ \\
\hline Low Density Lipoprotein (LDL) & $23.59 \pm 7.29$ & $17.12 \pm 7.39$ & $22.25 \pm 7.19$ \\
\hline High Density Lipoprotein (HDL) & $27.87 \pm 2.08$ & $33.28 \pm 2.28$ & $25.25 \pm 2.18$ \\
\hline Very Low Density Lipoprotein (VLDL) & $30.58 \pm 2.03^{\mathrm{a}}$ & $24.42 \pm 1.83 \mathrm{~b}$ & $25.97 \pm 1.93^{\mathrm{b}}$ \\
\hline
\end{tabular}

Table 3: Varying Doses of Cocos Nucifera Water on Lipid Profile of Broiler Chicks

Mean Is \pm SEM. Mean Values on the Same Row with Different

Superscripts Are Significantly $(\mathrm{P} \varangle 0.05)$ Different

The non-dose dependent significant $(\mathrm{P} \varangle 0.05)$ rise in serum activity of alanine aminotransferase of broiler chicks is presented in table 4. This was at variance with the report of Offor et al (2014) on effect of Cocos nucifera water on liver enzymes 
where a dose dependent reduction in activities of alanine aminotransferase (ALT), aspartate aminotransferase (AST) and alkaline phosphate was reported in wistar albino rats. The increased serum activity of ALT as observed in this experiment may probably be due to leakage of enzymes on slight agitation of blood at the point of collection. This may also be the reason for obtaining higher serum ALT activities at lower doses of experimental materials as observed in this study. The serum activity of aspartate aminotransferase (AST) was not significantly affected by both trial doses relative to control. Ast is important in the breakdown and elimination of nitrogen. High levels indicate muscle damage, heart muscle damage, liver damage, inflammation and various metabolic disorders whereas low levels indicate starvation or malnutrition. There was however, a dose dependent significant decrease in serum activity of alkaline phosphatase (ALP) of broiler chicks exposed to the trial doses relative to control. This observation is in agreement with the report of Offer et al (2014) who reported a decreased dose dependent activity in serum enzyme (ALP) of albino rats tested with Cocos nucifera water. ALP is important in metabolism and is found in liver cells. High levels indicate bile duct obstruction Cushing's liver disease, certain drugs such as steroids, or malnutrition (Ruben, 2016). Elevated levels of serum enzymes generally indicate cellular leakage and loss of functional integrity of cell membrane in organs such as liver Saskia et al (2014) and decreased level of activities indicate intact and normally metabolizing cells which are impermeable to enzymes (Numakani et al, 1999).

\begin{tabular}{|c|c|c|c|}
\hline Marker Enzymes(U/ L) & \multicolumn{3}{|c|}{ Dosage of Administration } \\
\hline $\begin{array}{c}\mathrm{T}_{2} \\
\text { Control T }\end{array}$ & $\begin{array}{c}\mathrm{T}_{3} \\
400 \mathrm{mg} / \mathrm{b} . \mathrm{wt} / \mathrm{day}\end{array}$ \\
\hline $\begin{array}{c}\text { Alanine Aminotransferase } \\
\text { (ALT) }\end{array}$ & $34.24+2.25^{\mathrm{a}}$ & $53.09 \pm 2.15^{\mathrm{b}}$ & $41.03 \pm 2.35 \mathrm{~b}$ \\
\hline $\begin{array}{c}\text { Aspartate Aminotransferase } \\
\text { (AST) }\end{array}$ & $51.58 \pm 3.08^{\mathrm{a}}$ & $51.94 \pm 3.18^{\mathrm{a}}$ & $55.07 \pm 2.98^{\mathrm{a}}$ \\
\hline $\begin{array}{c}\text { Alkaline Phosphate } \\
\text { (ALP) }\end{array}$ & $50.38 \pm 3.21^{\mathrm{a}}$ & $43.53 \pm 3.41^{\mathrm{ab}}$ & $37.35 \pm 3.41$ \\
\hline
\end{tabular}

Table 4: Effect of varying Doses of Cocos Nucifera Water on Hepatic Marker Enzymes

Mean Is \pm Sem. Mean Values on the Same Row with Different

Superscripts Are Significantly $(\mathrm{P}<0.05)$ Different

\section{Conclusion}

Cocos nucifera water, although did not significantly improve body weight and organs' weighs of broiler chicks at the tested doses, its positive response to blood lipids is commendable. The use of coconut water in broiler production above $400 \mathrm{mg} / \mathrm{kg}$ body weight of bird should be discouraged due to its negative effects on haemoglobin concentration (even though not correlated with total RBC counts), mean corpuscular haemoglobin concentration (MCHC) and alanine amino transferase activity. Since the production of healthy birds is the chief corner stone of poultry enterprise, the use of Cocos nucifera water as additives or growth promoters in poultry production should be conducted with caution.

\section{Reference}

i. Ameen, S.A., Adedeji,O.S, Akimgbade,A.A.,Olayeni,T.B., Ojedapo, L.O and Aderinola, O.A(2007). The effect of different feeding requires on haematological parameters and immune status of commercial broilers in derived savannah zone of Nigeria. Proceeding of 32nd Annual Conference of the Nigeria Society for Animal Production(NSAP) pp 176-178.

ii. Augustine S.P (2007). Wine produced using tender coconut and product. Potent us 2007 / 017897

iii. Basu,P Ghosh, R.N., Grove, L.E, Klei, L. and Barchowsky,A.C(2008). Angiogenic potential of 3-nitro-4- hydroxy benzene arsenic acid (Roxarsone).Environmental Health Prospect 116:520-523. Doi=10.1289/ ehp.116-a520.

iv. Belfield, A and Goldenberg,D.M. (1971). Colorimetric determination of alkaline phosphotase activity. Enzymes vol.12(5):561-568

v. Bozkurt,m.k,Kucukyclmaz,A.U., Catli and Cinav,M(2005) Effects of dietary antibiotics mannan oligosaccharide with or without oregano and hop supplementation on the growth performance and careers characteristics of male broilers. In Proceeding of $15^{\text {Th }}$ European Symposium on Poultry Nutrition.pp 285-28.7

vi. Burstein,M.P., and Samaelle,B.L.(1960). Estimation of very low-density lipoprotein cholesterol.Annals of Clinical Chemistry, 5: 609-611.

vii. Campbell-falck, D. Thomas, T., Falck, T. M, Tutuo, N and Clem. K (2000). The intravenous use of coconut water. Am. J. Emerg. Med. 18: 108-111.

viii. Conis (2011).http:ll study tiger.com essay-cocos nucifera coconut water as natural growth enhancers.

ix. Deleon, S. Y. Delores. M.I.(2005).Coconut in barrett Dm,somogyi L.P,Lamaswamy H.S (Eds).processing fruits: Science and Technology

x. Del Rasario,J.E., Bergonia, H. A, Flavier, M. E, Samonte, J. L. and Mendoza, E. M. T. (1984). Chromatographic analysis of carbohydrates in coconut water. Trans.the Nat.Acad.Sci.Technology.6: 127-151. 
xi. Ediriweera, E. R. H. S. S. (2003). Medicinal uses of coconut (Cocosnucifera L.). cocoinfo int.10:11-21 Friendewald, W, T., Levey, R. T. Freedickson,D.S(1972).Estimation of concentration of LDL cholesterol without the use of plasma ultracentrifugation .Clinical Chemistry, 18:499-520

xii. Jain, N.C(1993). Essential of veterinary haematology Lea and Febiger. Philadelphia.USA.pp 133-168

xiii. Jane Heart (2013). Coconut water. and oil Michigan State University Extension Kelly Reynold msu Dietetic International

xiv. Lapitan,O.B and Mabesa,R.C (1983). Chemical and Sensory characteristics of laguna and golden coconuts (Cocos nucifera L). Phillip Agric, 66:144150.

xv. Muller, H., Lindman, A. S., Brantsaeter, A. L. and Perderson J. I. (2003). The serum LDL/ HDL cholesterol ratio is influenced more favourably by exchanging saturated with unsaturated fat than by reducing saturated fat in the diet of women. Journal of Nutrition. 133:78-83.

xvi. Numakami, K. Y., Aoki, Y., Ogawa, Z. and Itoh, H. (1999); A kinetic model of mitochondrial aspartate aminotransferase transmigration in hepatobiliary disorders. Analytical Clinical Biochemistry, 36; 226-232.

xvii. Offor, E. C., Adeteramic, O., Novali, B. U., Igwenyi, I. O. and Afiukwa, C. A. (2014). Effect of Cocos nucifera water on liver enzyme, Middle East Journal of Scientific Research, 21(5): 844-847.

xviii. Ogundiya, M. O. (1991) Glucose content of coconut water in four varieties of coconut palm (Cocos nucifera). Journal of Science, Foods \& Agriculture, 56; 399-402.

xix. Ojebiyi, O. O., Farinu, G. O., Togun, V. A., Akinlade, J. A., Aderinola, O. A, Olayeni, T. B. and Moronfolu O. O. (2007). Studies on growth and hematological attributes of weaned rabbits fed graded levels of sun dried cassava peel-blood meal mixture. Proceeding of the 32nd Annual conference of the Nigerian Society for Animal Production pp. 213-216.

xx. Osazuwa, O. E., and Ahonkhai, I (1989). Coconut water as growth medium for micro-organisms. Nigerian Journal of Palm Oil Seeds, 10-11: 91-95.

xxi. Parades, A., Dornier, M., Nafissaton, D., Pain, J. P. (2007). Coconut water, uses, composition and world proportion fruits, vol. 67(2): 87-107.

xxii. Probir, K. G., Paramita, B., Souvila, M. and Mousumi, P. S. (2014) Physicochemical and phytochemical analysis of copra and oil of Cocos nucifera L. west coast tall variety. International Journal of Food Science. Id 310852. Hindawi. Vol. 2014; 1-8.

xxiii. Pue, A. G., Rivu. W., Sundarvao, C, and Sign, K(1992). Preliminary studies on changes in coconut water during maturation of the fruit. Sci. New Guin 18: 81-84.

xxiv. Pummer, S. Heil, P. Maleck, W, Petroianu, G. (2001). Influence of coconut water on lenwstatis. American Journal of Emergency Medicine, 19: 287-289.

xxv. Qureshi, A. A. Burger, W.C. Peyorson, D. M. and Elson C. E. (1986). The structure of and inhibitor of cholesterol biosynthesis isolated from barley. Journal of Biological Chemistry.261: 10544-10550

xxvi. Reitman., SR, and Frankel, S. (1957). Determination of aspartate and alanine aminotrasferases activity in blood serum and tissues. American Journal of Clinical Pathology, 28: 56-64.

xxvii. Rethinam, P. and Kumar, T. B. N(2001). Tender coconut an overview. Indian Coconut Journal, 32: 2-22.

xxviii. Richmond, W (1973). Cholesterol enzymatic colorimetric test (CHOP-PAP) for estimation of total cholesterol and HDL cholesterol in serum. Clinical Chemistry. 19: 1550-1556.

xxix. Richter, E.M. Jesus. D. P. deMunos, R. A. A. Lago, GLD. Agnes L. (2005). Determination of anions, cations and sugars in coconut water by capillary electrophoresis. Journal of Brazilian Chemical Society. 16: 1134-1139.

xxx. Ruben, D. (2016). Understanding blood work: The complete blood count (CBC). Biochemical Profile.

xxxi. Saat, M, Singh, R. Gamiini Serisinghe, R and Nawawi, M (2002). Rehydration after exercise with fresh young coconut water, carbohydrate-electrolyte beverage and plain water. J., Physiol. Anthropol. Appl. Hum. Sci. 21: 93-104.

xxxii. Sanchez, P. C., Colloct, L. S, Garpacio, C. L and Lapityan, H (1985). Village level technology of processing coconut water vinegar. Philipp. Agric. 439-4448.

xxxiii. SandiBusch (2014). Facts on coconut oils, nutrients Healthy eating. Iframe src SF Gate Id=GTM Waz=CHF

xxxiv. Saskia, R, Gudrun de Boeck, Hilde De Cock, Ronny, Bard Lieven, B (2014). Accumulation and detoxification of metals and arsenic in tissues of cattle (Bos taurus and the risk for human consumption). Sci. Total Environment, 466-467: 175-184.

xxxv. Steiner, I and Desser, A. (2008). Coconut water, composition, properties and processing Emahr, 32: 513-516.

xxxvi. Study tiger, com(2016). Cocos nucifera water as natural growth enhancer for gallus, gallus domesticus (Broiler chickens). Essay park Avenue, New York, NY 10022.

xxxvii. Sturkie, P. D. (1965). Avians physiology. Comstock publishing Association. New York

xxxviii. Togun, V. A and Oseni, B. S. A. (2005). Effect of low level inclusion of biscuit dust in broilers' finisher diet on pre-pubertal growth and some hematological parameter of un-sexed broilers. Research communication Animal Science 1(2): 10-14

xxxix. Tohola, SH (2010). The relationship between blood lipid profile and performance of broilers fed two types of Finisher diets. Iraqi Journal of Veterinary Science 24(2): 87-91.

xl. Trinder, P. (1969). Triglyceride estimation by GPO-PAP method Annals of Clinical Biochemistry, 6: 24-27.

xli. Uphade, B. K, Shelke, S.S. and Thorat, D.G (2008). Studies on some physicochemical characteristics of coconut water near sugar and chil emical factory. Kopergaon (M.S). International Journal of Chemical Science 6: 2052-2054. 